\title{
EIIAS OF POWER
}

\section{FI ANCES FOX PIVEN and RICHARD A. CLOWARD}

During the past few years a strong challenge has been niounted in the pages of Monthly Review to the argumentprevalent on the left as well as the right-that globalization and technological change have combined to bring us into a $r$ ew era. Ellen Meiksins Wood captured the gist of the emergi ig $M R$ position in an essay entitled "Modernity, Postmoderr ity, or Capitalism" in which she asserts that there has been I o historic rupture, no epochal shift, to usher in globalization ( $r$ postfordism or postmodernism. All these concepts have "the effect of obscuring the historical specificity of capitalism" "hich "by definition means constant change and develop!nent...." What we are witnessing is the diversification and :xtension of the old logic of the mass production economy. ${ }^{1}$ 'This is capitalism.'

We agree with much of the empirical basis for the $M R$ shallenge to the new catechisms about globalization and echnological change. We agree, for example, with the arguments, made variously by Wood, Tabb, and Henwood in the pages of Monthly Review, and by Gordon, Zevin, Hirst, and Thompson, and others elsewhere, that the competitive pressures in domestic markets attributed to increased global trade and capital movement have been vastly overstated, especially

Frances Fox Piven and Richard A. Cloward are co-authors of The Breaking of the American Social Compact (New Press, 1997). 
with regard to the United States, which remains less exposer! to international trade and capital flight than most other ricl industrial countries. ${ }^{3}$ And we also agree that much of this $i$; not really new in any case, that international integration characterized earlier periods of capitalist development, par . ticularly the years before the First World War.

But if the system is basically the same, why is so mucl changing? In particular, why are class power relations chang ing? The evidence is considerable. Unions, once the bedrocl of working-class power, are on the defensive, losing member in most capitalist countries, and in Britain and the Unitec States, losing battles as well-at least when they dare to figh them. ${ }^{4}$ Meanwhile, historic left parties are refashioning them selves as the champions of neoliberal policies, and turning their backs on the organized working class that was once thei1 base. Welfare state protections, the main political achieve ment of the industrial working class, are being whittled back in the interest of labor market "flexibility;" cutbacks in socia! benefits intensify worker insecurity, smoothing the way for lower wages and less secure conditions of employment. Anc inequalities are widening, especially in Britain and the Untied States, where income and wealth inequalities are spiraling tc nineteenth-century levels.

To be sure, it still is capitalism. But we think the innovation and development characteristic of capitalism is interacting with shifts in class power to produce convulsive changes not only in patterns of production and exchange, but in patterns of culture and politics. And, contrary to Wood, we think these developments are usefully characterized as ruptures with the past, the continuities of capitalist social relations notwithstanding. Indeed, we think such ruptures have studded the history of capitalism, sometimes affecting particular industries, but sometimes transforming entire societies. Capitalism develops not only through gradual and incremental changes propelled by the logic of accumulation, but also through wrenching upheavals forged by momentous class power conflicts, as when the organization of steel production was transformed by smashing the craft workers in the nine- 
te $n$ th-century United States, or when public sector unionism wi s crushed in the post First World War period. And, again contrary to Wood, we think such upheavals are sometimes so b: oad in scope and consequence that they usefully demarcate d stinctive eras or epochs. The events which culminated in the tc rmination of English poor relief in favor of an "unreguli ted" market in labor in the 1830 s marked such an epochal $c$ lange, which the intense protests of the Chartist movement $c$ suld not reverse. It may be that the interplay of contempo$r$ iry economic restructuring and power shifts in the advanced capitalist countries, and especially in the United States, is also e pochal in its significance. In any case, it is a class power s ruggle which has to be understood in power terms, a predatory mobilization by capitalists made possible by working-class reakness and disarray, although justified in economic terms is the result of new market imperatives.

We make our argument about power upheavals in two sarts. First, we discuss the theoretical basis for the longstandng left conviction that labor power is rooted in capitalist production relations, and in the organization of workers for political power that production relations facilitate. $M R$ authors share this conviction, and so do we. Second, and this is our more distinctive argument, we think that actualization of the power is by no means automatic or inevitable, but is realized only over time and with difficulty, as ordinary people penetrate dominant ideologies, build the solidarities that make the actualization of power possible, and challenge the rules which guarantee their quiescent co-operation. The disturbances which ensue as people discover and act on the power capacities yielded them by specific forms of economic and political organization lead to new institutional arrangements: the creation of a social compact to conciliate popular forces, while also regulating and caging them. Economic change may shatter these achievements, not because capital no longer depends on labor in the abstract, or because state rulers no longer depend on mass publics, but because the 
painfully constructed forms of popular understanding an 1 organization, which made possible the realization of some power from the bottom, weaken. The erosion of popular power capacities in turn smooths the way for new assertior $s$ of power from the top. Capital breaks the social compact which working-class power made necessary. By doing so, however, it may also unleash new possibilities for popular struggle.

Capitalist societies organize production and exchang: through networks of specialized and interdependent activi. ties. These networks of co-operation are also networks o contention. They help to shape the interests and values whicl give rise to conflict. More important for our argument, net works of interdependency also generate dispersed power ca pacities. Agricultural workers depend on landowners, bu landowners also depend on agricultural workers, as industria capitalist depend on workers, the prince depends in some measure on the urban crowd, and governing elites in the modern state depend on the acquiescence if not the approval of enfranchised publics.

Actual power relations are of course tangled and intricate, since urban, democratic, and capitalist societies generate multiple and cross-cutting forms of interdependence. We take for granted, however, that some relationships are much more important than others. The dominant interdependenciesand the power constellations they make possible-develop within economic relationships, and within the relations which anchor state elites to the societies they rule. Thus dominant interdependencies, and dominant forms of power, reflect the co-operative activities that generate the material bases for social life, and that sustain the force and authority of the state. If workers withhold their labor, production stops; if they withhold their votes, regimes fall. And, of course, the one set of relations is deeply intertwined with the other. States define and enforce property rights, regulate money and credit, and regulate the relations between employer and employees, for example. ${ }^{5}$ The relations between class-based interest groups and state authorities inevitably focus importantly on these economic policies. And the broadly parallel evolution of in- 
$\mathrm{d}$ istrial capitalism and electoral-representative institutions in the twentieth-century means that working-class economic cliallenges are systematically transported into the relations b stween voting publics and the state.

This emphasis on power capacities shaped by the inter$\mathrm{d}$ ependent relations which constitute economy and polity is c early consistent with the Marxist view of working-class power a rooted in the role of the proletariat as a force in capitalist production. It is, we should note, also consistent with other i) nportant theoretical traditions, including, for example, Norbert Elias' depiction of the development of European central $s$ ates as propelled by the dynamics generated by the networks cf interdependency which developed among the warrior rule rs of these societies. ${ }^{6}$ And it fits Schumpeter's model charac$t$ :rizing the capitalist state as the "tax state" which, because it c epends on economic resources it does not control, ties state a uthorities in close interdependence with the owners of private property who do control those resources.

The left confidence in working-class power was also expressed in the belief that working-class power would grow. Marx I ad rooted the growth of proletarian power in the development of industrial capitalism; Bernstein saw roughly parallel possibili1 ies for working-class power in the development of electoral] epresentative arrangements. Social democratic perspectives jater melded the power yielded workers by industrial capitalism "vith the power generated by electoral representative arrangenents, so that working-class power resources were said to grow n tandem with both industrial capitalism and electoral denocracy. ${ }^{8}$ In the happiest variants, these power resources esulted in a welfare state compact which promoted the "de:ommodification" of labor, and therefore a fundamental emowerment of labor in market relations. ${ }^{9}$

A broadly compatible view of the growth of working-class power is incorporated in the work of historians dedicated to recovering the history of "protest from below" in preindusrial Europe, such as Eric J. Hobsbawm, George Rudé, and Charles Tilly. Even pluralist analysts point to the interdependencies of voters and political elites generated by liberal democ- 
racy itself, arguing that periodic elections and an enfral1chised mass public forces elites to defer to the popular will. One variant or another of this optimistic perspective $h_{i} s$ nourished the left for at least a century and a half.

With these points made, it is clear that the globalizatio ? thesis cuts to the core of left political conviction. The effective exercise of labor power has always been premised on the limited ability of capital to exit or threaten to exit frol 1 economic relations. Globalization, together with postfordi: $t$ production methods, seems to open unlimited opportunitic s for exit, whether through the relocation of production, acce erated trade, worker replacement, or capital flight, all of which seems to radically reduce the dependence of capital o: 1 labor. Workers, for their part, tied as they are by their merel / human fear of change and rupture, can never match thes: exit options. And while working-class voters may still be abl: to make regimes topple, the significance of voting powe depends on the significance of state power. But, so the argu. ment goes, states whose sovereignty is confined to fixed terri tories also must knuckle under to the whims of a mobil, capital. Economic globalization thus presumably eviscerate: both economic and political forms of working-class power. A a result, workers and voters in the mother countries of capi talism are now pitted against low-wage workers and feeble governments everywhere, and pitted against technologica advances as well. So, if the globalization thesis is true, it is devastating to the left as we have known it.

No wonder the determination with which $M R$ authors (and we as well) scrutinize and challenge the argument. But scrutinizing and disputing the extent of global trade or capital movement does not quite grapple with the realities of class power under new conditions. What is at issue is not simply whether it is still capitalism, or whether capital is still dependent on labor in the abstract, or whether nation states still matter, but whether economic changes have undermined the conditions which once made at least the partial actualization of economic and political power from the bottom possible. 
II

Over the broad sweep of Western and capitalist developr ıent, the old idea that working-class power will grow as c apitalism develops may yet prove to be correct. There are some strong theoretical reasons for thinking so. If power is rooted in interdependent relations, then the increasingly t laborate division of labor that characterizes capitalist societes, as well as the continued penetration of the core into the periphery with the consequent absorption of previously marginal groups into the capitalist division of labor, would diffuse jower capacities more and more widely. (Our reading of the political implication of Durkheim's idea of the growth of ' rganic solidarity is similar: a tighter grid of interdependenies means that everyone in the grid has some leverage, at least inder some conditions.) This line of reasoning reverses the onventional wisdom: it is not decentralization but centralizaion and the integration that it implies that enlarges at least he abstract possibility of popular power. The remote village nay be shielded by its remoteness from a predatory state or a predatory capital, but neither can it have influence on the tate or capital until it is brought into some kind of relationship with them.

But while capitalist development increases the potential power of working class and previously marginal groups, it can also work to impede the actualization of that power potential. Whatever is true in principle of the advancing division of labor, the power capacity of lower strata groups has certainly not advanced smoothly. At the very least, there have been periodic sharp reversals, and we appear to be witnessing such a reversal now.

In principle, economic and political organization yields power to all parties who make necessary contributions to economic or political processes. In principle, workers in a capitalist economy always have potential power over capitalists, whether they labor as agricultural tenants, or as industrial workers, or as technicians in a postindustrial economy. In principle, they have power because their contributions are 
necessary to ongoing processes of production and exchang:. But the actualization of those power capacities is condition: 1 on their ability to withhold or threaten to withhold their co-operation, and this capacity depends on other features i $f$ worker-employer relationships beyond the fact of interdeper dency. To understand class power dynamics, and especially t ) understand the impact of postindustrial changes on worke $r$ economic and political power, we have to pay attention to th: ways that economic change affects the ideas and capacities fo: organization of working-class groups, and their ability to with stand threats of capital exit or deploy threats of exit them selves.

The first condition for the assertion of power from below" is that people recognize their contribution to economic anc political life. Economic and political interdependencies ar real in the sense that they have real consequences. But the: are also cultural constructions. To be sure, if people do in fac; have agency, which we take to mean at minimum some ability to penetrate a dominant ideology, and some capacity to acl outside the rules which strip them of power, then the very fact of participation in interdependent activities would incline them to recognize their contributions, and therefore their power capacities. Perhaps so, or at least to some extent, or at least under some conditions. ${ }^{10}$ But such recognition must always overcome inherited and deeply imprinted interpretations which privilege the contributions of dominant groups, ${ }^{11}$ and must also overcome the continuing ability of dominant groups to project new and obscuring interpretations.

Second, since the relevant contributions to ongoing economic and political activities typically involve numerous individuals, people must develop a sense of solidarity and some capacity for concerted action so that their collective leverage can be deployed against those who depend on them, for work, votes, or acquiescence in the rules of civic life. This is the classical problem of organizing, whether workers, or voters, or community residents. And finally, the threat of exit, including the threat that employers will turn to replacement workers or that politicians will court alternative voter blocs must be 
1 mited, or at least the prospect of exit must not be so fright$\epsilon$ ning that people cannot imagine enduring it.

These conditions for the realization of class power, and the ability of groups to manipulate them, depend on very s pecific and concrete historical circumstances. To appreciate t his, we have to forgo our tendency to speak of classes and systems. For some purposes, these abstractions are of course $i$ iseful. But the interdependencies which sometimes make : issertions of popular power possible don't exist in general or in the abstract. They exist for particular groups, who are in articular relationships with particular capitalists or particuar state authorities, at particular places and particular times.

Economic changes can be significant not because class nterdependencies evaporate, but because economic change, specially rapid and uneven change, transforms these conzrete particularities. People recognize their leverage over particular employers, not over capital in general, although hey are surely influenced by more general ideas about the relationship of employers to employees. They recognize commonalities and capacities for collective action among members of particular concrete groups far more readily than among the working class in general, although here too broader group identities and antagonisms may predispose them one way or the other. And people fear the loss of particular forms of employment to which they have access, and in the particular places where their lives are rooted, although once again they are surely more likely to be alert to these dangers if they think capital exit is a more widespread phenomenon. The decline of hand-loom weaving in nineteenth-century England is an example, for it did not mean that manufacturers no longer depended on labor. But it did mean that the hand-loom weavers and framework-knitters could be starved out as manufacturers turned to women and children to work in the new mills. And as this happened, the understandings, forms of solidarity, and strategies for controlling exit, developed in an earlier era of putting-out manufacturing, eroded. 
Thus, while capital still depends on labor in genera], ongoing contemporary economic changes are underminin! the ideas, the solidarities, and the strategies for curbing exi threats that were developed by concrete groups under the concrete circumstances of industrial capitalism. The old oc cupational categories-the miners, the steelworkers, the dockers, and so on-that were at the forefront of labor strug gles have been depleted. And those who remain no longes have the confidence that they can act to "shut it down," paralyze an industry, and even make an entire economy falter Meanwhile, the working-class towns and neighborhoods are emptying out, the particular working-class culture they nourished is fading. The unions that drew on all of this are necessarily enfeebled. They are enfeebled even more by employer strategies that take advantage of the decline of older forms of working-class power to launch new and terrifying exit threats-by hiring contingent workers and strike replacements, by restructuring production, or by threatening to close plants or to shift production elsewhere.

Incessant talk about globalization and downsizing figures indirectly in all of this, as the rise of an ideology that asserts the necessary and inevitable autonomy of markets and therefore of capital, a resurrection of nineteenth-century laissez-faire doctrines about the unregulated market now expanded to world scale. But none of this talk would be especially forceful by itself. The ideology is frighteningly persuasive not only because it is heard on all sides, but because it appears to explain the decline of concrete and particular working-class groups. Globalization talk gains force not from abstract generalities about trade and capital movement, but when jobs are cut or restructured, when trucks labeled "Mexico" pull up to a striking plant, or simply when a business moves across the state line.

III

Understandably, there is a good deal of nostalgia for the working-class formations of the industrial era. We are all social democrats now, so to speak, and we mourn the passing of the 
o d sureties of the mass strike, of big union and of labor parties w nich help to produce not only welfare state protections, but the political legitimation of the industrial-era working class. A ll of this was won not only because the economic and political $r$ lations of the industrial era made capital dependent on worke's in the abstract, but because people in specific situations c juld make that dependence work for them. The loss is awesome.

But there is another face to economic change. Economic c nange weakens old forms of working-class power, and frees capital to smash the compact that power from below made recessary. This means new hardships, especially for more r ulnerable groups. But it also means a kind of liberation from the constraints which were a condition of whatever concessions the compact granted. Federal protection for the right to ( rganize was a victory. So was union recognition by the big industrialists a victory. These victories did not come unencumlered, however. They brought with them a new regime of abor regulation which limited the right to strike, encouraged mion oligarchy, and allowed employer influence to gradually ncrease over time. Now, as the old victories are whittled away, he curbs on popular politics imposed with them may lose orce. If they do, the possibilities of new surges of disruptive politics from below will increase.

Meanwhile, economic change also creates concrete new oossibilities for worker power. People work at new and different occupations, they have different skills, and in time they will see the power potential inherent in the interdependencies of a new and fabulously complex and precarious communications-driven economy that is as vulnerable to mass disruption as the manufacturing-driven economy was. In time, maybe only a little time, they will develop the awareness of commonalities and capacities for joint action which will make working-class power possible again. And they are also likely to find the imagination and the daring to break the new rules governing communications which are even now being promulgated to criminalize the exercise of power from below.

It is the end of a power era. It is also the beginning of a power era. 


\section{NOTES}

1. Ellen Meiksins Wood, "Modernity, Postmodernity, or Capitalism?" Month:" Review, vol 48, issue no. 3 (July-August, 1996) p. 34.

2. Ibid p. 38.

3. Doug Henwood, "Post What?" Monthly Review,vol 48, issue no. 4 (Septembe1 1996); Doug Henwood, "Talking About Work," Monthly Review, vol. 49, issue nc 3 (July-August, 1997); William K. Tabb, "Globalization is an Issue, The Powe of Capital is the Issue," Monthly Review, vol. 49, issue no. 2 (June, 1997). See als David Gordon, "The Global Economy: New Edifice or Crumbling Founda tions?" New Left Review, issue no. 168, (March/April, 1988); Paul Hirst ane Grahame Thompson, Globalization in Question: The International Economy and th Possibilities of Govermance (Cambridge: Polity Press, 1996); and Robert Zevin "Our World Financial Market is More Open: If So, Why and with What Effect' Financial Openness and National Autonomy; Opportunity and Constraints, ed. Tarig. Banuri and Juliet Schor (New York: Oxford University Press, 1992), pp. 45 anc 72. Zevin concludes after a careful examination of trends in world financial markets that "there is no convincing evidence that the policy/political 'discipline' of the capital markets is greater than it ever was." Indeed, he sees no trend toward financial openness not only over the past century, but over the last three centuries. There are disagreements in this emerging school of skeptics, of course. For example, Tabb seems to think technological change is more important than does Henwood, and Zevin also argues persuasively that financial trends have not been influenced by communications technology.

4. Bruce Western, "Union Decline in Eighteen Advanced Capitalist Countries," American Sociological Review, vol 60, issue no. 2 (April, 1995).

5. For a discussion, see Fred Block, "The Roles of the State in the Economy," The Handbook of Economic Sociology, ed. Neil J. Smelser and Richard Swedberg (Princenton: Princeton University Press, 1994).

6. Norbert Elias, Power and Civility: vol. II of The Civilizing Process (New York: Pantheon Books, 1982).

7. Joseph Schumpeter, "The Crisis of the Tax State," Joseph A. Schumpeter: The Economics and Sociology of Capitalism, ed. R. Swedberg (Princeton: Princeton University Press, 1991).

8. See for example Walter Korpi, The Democratic Class Struggle (London: Routledge and Kegan Paul, 1983).

9. On decommodification, see Gosta Esping-Andersen, Politics Against Markets: The Social Democratic Road to Power (Princeton: Princeton University Press, 1988) and The Three Worlds of Welfare Capitalism (Princenton: Princeton University Press, 1990); and see also Frances Fox Piven and Richard A. Cloward, The New Class War (New York: Pantheon Books, 1985). Other class analysts saw the welfare state as less the expression of working-class interests, and more the instrument for the domination of workers, although this analysis has lost salience as welfare state programs have come under attack. 
0. Barrington Moore, Social Origins of Dictatorship and Democracy (Boston: Beacon Press, 1966), and before him Alexis de Tocqueville The Old Regime and the French Revolution (New York: Doubleday Anchor Books, 1955). Both seemed to think that the recognition of interdependencies was inevitable when they argued that peasants would come to see the extractions of a predatory landed aristocracy as unjust unless those extractions were balanced by contributions to the peasant community.

1. This includes of course the interpretations produced by intellectuals which privilege the contributions of dominant groups. A curious example is in the literature on exchange theory, which advances a definition of power as rooted in the exchange of services and benefits, and is thus at the outset similar to our definition. But the drift of this literature, and particularly of the work of Peter Blau, is to define power in relationships as the result of furnishing needed contributions, a tautology that of course works to justify unequal power.

\section{(Continued from inside back cover)}

The gaps are likely to be more deeply felt now that history seems to be moving in exactly the opposite direction to the current intellectual fashions. The prospects of a renewed left politics seem more promising now than anyone would have dared to believe just a little while ago. The labor movement shows signs of being on the move again. The most cursory scan of the mainstream press reveals that even-or especially-the mouthpieces of capital are nervously noticing a shift in the wind. Consider, for instance, the bad-tempered outbursts about the power of organized labor during the recent flap over Clinton's defeat on "fast-track."

Yet at just this critical moment, the intellectual resources of the left are somewhere else. It's hard to think of another moment in history when there has been a wider gulf between left intellectuals and what's actually happening on the ground.

So we now think that $M R$ should, occasionally, do what it can to fill some of the gaps. We have no intention of abandoning our own specific project, but from time to time, we'd like to try something a little different. Without ever abandoning our commitment to clarity, we'd like, once in a while, to run slightly longer pieces and debates, on major questions of special concern to socialists in today's historical conditions. We hope that these debates will, among other things, provide a useful tool for educators-in schools, universities, labor organizations, and other institutions where people are working to awaken a critical consciousness.

In this issue, we're running a debate of that kind, and we hope to run others in the future. We'd like to hear from readers what you think, and we' $d$ be especially interested in hearing any suggestions from you about the issues that most demand this kind of treatment.

It is with deep regret the we announce the death of Monthly Review author Daniel Nugent (1954-1997). Daniel was a professor of anthropology and Latin American history, his writings include Spent Cartridges of Revolution: An Anthropological History of Namiquipa, Chihuahua (1993). Last year he collaborated on a play, 13 Dias/13 Days: How the Zapatistas Shook the World, performed on tour by the San Francisco Mime Troupe. 


\title{
CLASS COMPACTS, THE WELFARE STATE, AND EPOCHAL SHIFTS (A Reply to Frances Fox Piven and Richard A. Cloware:)
}

\author{
by ELLEN MEIKSINS WOOD
}

Frances Fox Piven and Richard Cloward have offered $u$; nothing less than a theory of history to challenge what the r call "the emerging $M R$ position" on globalization. Thei argument has to be met seriously on its own terms, with a] । alternative historical analysis-especially since they are fa. from alone in describing globalization as the end of an era and as the breaking of a compact between capital and labor.

\section{A Social Compact Between Capital and Labor?}

The political moment is grim. The measures won by working clas: and poor people over the course of the last century, measures whicl humanized Western capitalism, are at risk. But they are not at risk because the structural imperatives of this new stage of capitalis development have made the social rights won in the past economi cally dysfunctional. Rather, they have been put at risk by the politica mobilization of some human actors against other human actors Capitalism and capitalists are on the move.... But capitalism has been on the move before, and with very similar ideas. It has also been halted before, and forced to concede the public spaces and socia] protections that make human life tolerable.

That is the essence of Piven and Cloward's political message, and behind it lies a historical analysis. For our purposes, the most important points in it are these: in the

Ellen Meiksins Wood is co-editor of Monthly Review. 
history of capitalism, periods of capitalist mobilization and a ssaults against labor have alternated with periods of strength f rr labor, when capitalists have been forced to make conces$s$ ons. Those periods of concession can be called a kind of $s$ sial compact. Such compacts are broken when capital again gathers strength and goes on the attack. Each compact and e ach breach represents an epochal shift, as one "power era" r:places another.

The current decline of the welfare state in this account $r$ epresents a moment of renewed attack by capital. "Globalization" has laid the foundation for it, undermining the power (f the working class by giving added plausibility to capital's ferennial threat, the threat to move elsewhere. But though lobalization has made it possible, the decline is not the 1 ecessary result of some impersonal and inevitable process, some "structural imperative." It stems from yet another political and ideological mobilization of capital.

There is much on which we agree. It is, I think, important 10 emphasize, as Piven and Cloward do, that what we're seeing loday is not just some inevitable natural process but a class inobilization, that what people are calling "globalization" is 1 lot just a structural imperative but a class strategy. At the same ime, though we may disagree about the constraints globalizaion does or doesn't impose on class struggle (I'll come back o that later), we agree-or seem to-that class strategies uren't constructed in a historical vacuum. Specific historical onditions-material, political, ideological-make some trategies possible while they rule out others.

But there are important disagreements too, which have ignificant political implications. I can sum up my disagreenents like this: Piven and Cloward give both too much and loo little credit to the "structural imperatives" of capitalism. Capitalism apparently establishes the outer boundaries be'vond which class struggle can't go, but it's not clear what limits capitalism places on class struggle within those boundaries.

To put it another way, Piven and Cloward attribute both too much and too little to class struggle. They expect too much of it in the sense that they count on it to make life tolerable 
within the confines of capitalism and the strictures of th 2 capitalist market. But in another sense, they ask too little of class struggle: the best it can do-occasionally and tempora ily-is to make life more bearable within the capitalist systemi. If (even in this "grim" political moment) they' re too optimi:tic about the sustainability of capitalism "with a human (or at least tolerable) face," they're too pessimistic about the possibility of transcending capitalism altogether.

Their account of historical change and epochal shifts i:i too simple a matter of alternations of class power betwee1 capital and labor: compacts are made as labor rises, and the are broken when labor declines and capital moves against it In their historical account, there are too many ruptures anc upheavals on the surface of capitalism, and not enough long term historical processes. The effect is to make, say, a changc of government or a single piece of legislation look like a majol historical shift, while continuities and changes in fundamen tal social property relations seem far less consequential. ${ }^{2}$

I can better explain what I mean by example, by looking at the two cases which most clearly illustrate their argumen about compacts and epochal shifts.

We can learn a great deal, first, by looking at their primary historical example of the kind of epochal ruptures that "transform entire societies," the events that culminated in the reform of the English poor laws in 1834. Before 1834, as far back as the Tudor era in the sixteenth-century, England had what was called "outdoor" relief-that is, relief generally provided by the parish, in the community and outside institutions such as workhouses. The nineteenth-century reforms were meant effectively to end outdoor relief. Piven and Cloward seem to be suggesting, then, that the old system represented something like a class compact, but that in 1834 capital broke that compact, subjecting labor to an "unregulated" market and ushering in a new era of capitalism.

How well does this account stand up? The Poor Law Reform of 1834 was intended above all to make relief to the poor less desirable (less "eligible") than the least attractive job available. (Sound familiar?) It certainly made life very 
i npleasant for those compelled to accept poor relief on its t.rms, and its ideological underpinnings were certainly, and consciously, the principles of the "free" market.

But this nasty piece of legislation was only one moment, i an especially unpopular one, in a long historical process, the subjection of direct producers to market imperatives, and the commodification of labor power. It's not even clear that the poor law reform of 1834 was an especially consequential looment in that historical process. As Eric Hobsbawm has : uggested, it is "improbable" that it "actually made labour : upply more flexible." 3 But in any case, the process of labor - ommodification, a slow process of transforming social prop-rty relations that stretches back at least to the sixteenth entury, was already far advanced before the Poor Law Reform vas passed. The subjection of production to market imperaives-and the effects this had in dispossessing direct producrs-was well established by the end of the seventeenth sentury; and by the end of the 18th, the principle that labor was a commodity to be bought and sold on the market, however much it continued to be fiercely contested, was firmly in place, in practice and in theory. If in the nineteenth century it was already irreversible by anything short of revolution, the poor law reform of 1834 had little, if anything, to do with making it so.

The 1834 Poor Law Reform certainly marked a significant political, and even more an ideological, moment. But it's hard to identify any single event-or even a series of eventsthat represents the establishment of an unregulated labor market in the kind of epochal shift Piven and Cloward are looking for.

What about the "interplay of economic change and power shifts" which for them is the motor of epochal change? What is the relevant power shift here? If anything, workingclass organization and militancy had been growing in the half century before the reform of 1834 , so it could be argued that the mobilization of capital was a response less to labor's weakness than to its growing strength. In fact, a convincing theory of history could be constructed in which capital has 
gone on the attack to head off the power of labor at least : $s$ often as to take advantage of its weakness. Be that as it may, $f$ we're looking for a specific political shift with an immediat 2 effect on the 1834 poor law legislation, the reform of th franchise just two years earlier is a likely candidate.

The franchise reform of 1832, which enfranchised som: cities hitherto without parliamentary representation, is ofte: 1 treated as the coming to power of the "bourgeoisie" and of industrial capital in particular. This is, to be sure, an over-sim plification, since many "bourgeois" already had the vote be. fore it, but more particularly because capitalism had lon: been established among the landed classes. Still, with thosi cautions in mind, it makes some kind of sense to see the Poo! Law Reform of 1834 as a result of a political "rupture,' formalized by an increase in the parliamentary representatior: of industrial capital. But is this what we mean when we speal: of an "epochal shift," a new "power era"?

In any case, what exactly did the poor law reform bring to an end? Did it end a regime of poor relief that clearly expressed the interests of the laboring classes, that clearly represented a concession to working-class power?

Underlying the English sytem of poor relief in all its forms was the sheer destructiveness of capitalism, the damage to the social fabric that is the inevitable result of a system in which human labor power and nature itself are treated as commodities and sources of profit. That system both requires and limits social measures to correct its destructive imperatives. Seen from that vantage point, the Tudor system of poor relief was the beginning of a long series of measures, including the modern welfare state, which have been adopted at various times throughout the history of capitalism to compensate for its own destructive, and self-destructive, logic.

Direct coercion has never been enough to deal with the threats to order which are the inevitable results of such a system. And a society in which increasing numbers of people were being separated from direct access to the land and the means of their own self-reproduction in historically unprecedented ways, while at the same time being detached from the 
raditional disciplines of dependence and communal regulaion, presented very specific problems of its own. Those problems in England, the first truly capitalist society, gave rise to a nore systematic form of poor relief than existed anywhere else in Europe at the time.

So we are, again, talking about a long-term process and the underlying logic of capitalism. The threat of social disorder and popular unrest is the inevitable outcome of that logic, and has been since the beginning. But if fear of disorder was always a strong motivation for the ruling class in England, there was never a simple correlation between the development of English poor relief and the rise of working-class power.

In the early stages of capitalism, for instance, in an economy not yet in need of factory labor, and unable to absorb the growing numbers of people dispossessed by the concentration of property in the hands of landlords-by direct coercion and by new competitive pressures-poor relief was, among other things, a response to the ruling class fear of lawless vagabonds and "masterless men." At other times, some forms of "outdoor" relief, by making the poor dependent on their parish, responded to the needs of agrarian capital for a regularly available force of cheap casual labor. In that sense, while outdoor relief was in many respects less unpleasant than the workhouse of the nineteenth-century (though we shouldn't romanticize it, nor forget the disadvantage associated with it; the immobility it was meant to impose on workers, the deliberate stigma often attached to it, and so on), it can hardly be called a conciliatory gesture to a strong laboring class.

At the same time, each of these changes in the needs of capital can be understood only in the context of resistance and struggle by subordinate classes. The long and continuous process of subjecting labor to market imperatives was also a continually contested process. Apart from daily struggles over the disposition of labor and its fruits, resistance took different forms in different periods: from the enclosure riots of the sixteenth and seventeenth centuries at a time when the landed 
class was consolidating its concentration of property, to the bread riots that punctuated the eighteenth century at a time when the propertyless poor were most vulnerable to rises in the price of bread. The contest was also marked by continuous ideological conflicts, among different definitions of property rights, between the "moral economy" of the subordinate classes and the increasingly dominant political economy of the exploiting classes, and so on. At every stage, social policy, including the poor laws, was forged in the crucible of that changing class struggle, and at every stage, fear of disorder and popular unrest was a major determining factor.

There came a time when the process of labor commodification was effectively complete-in the sense that the dominant form of labor was now performed by permanently propertyless workers compelled to sell their labor power for a wage, not intermittently or seasonally but continuously and always. This brought with it new forms of class organization, notably trade unions, and new forms of struggle, notably strikes. It also created new social problems and new contradictions in capitalism.

Capitalism, as we all know, needs a vast reserve of labor compelled by economic necessity to sell its labor power. Yet at the same time, capitalism has always been and will remain unable to put the whole of its dispossessed labor force to work at the same time. So an advanced capitalism, which needs a vastly larger proportion of the population as a potential labor force than the system could employ in its earlier days, always has to strike a complicated balance. It has to keep that reserve army alive and ready for work while also keeping alive the economic imperatives that will compel labor to work when capital needs it.

Capitalism needs, in other words, both to maintain some kind of minimal social provision and to subject workers to the ruthless compulsions of the market. That delicate balance can never be completely upset without destroying capitalism. But the relative weight of social provision and market imperatives can shift in response to economic cycles and crises, and it is constantly subject to class struggle, which can push the bal- 
ince more in favor of social provision, as in the modern velfare state.

To sum up, then: there is no identifiable "power era" in which poor relief or other forms of social provision have responded clearly to the needs of labor. At the same time, here is no era in which resistance and struggle have not been essential determining factors. From the beginning, the developing capitalist system has been subject to its own destructive mpulses-the drive to exploit to the limit its human and natural substance, and to tear apart the social fabric with its ruthless imperatives of commodification, accumulation, and self-expansion. From the beginning, those destructive imperatives have been resisted by class struggle. From the beginning, constant corrective measures have been needed to counteract or compensate for those destructive imperatives; and from the beginning, though in constantly changing forms, state intervention has been an indispensable corrective. From the beginning, too, the struggles of the laboring classes have pushed the state in that direction, with the paradoxical effect that capitalism has often been saved from itself by class struggle. In this constantly conflictual process, some moments have no doubt been better for workers than others. But in this long history of conflict and change, where is the compact, and where is the breach?

\section{Globalization and the End of the Welfare State "Compact"}

Piven and Cloward tell a story about globalization analogous to the history of the earlier "compact." Proponents of what they call the "globalization thesis" have, they agree, exaggerated some of its consequences, but globalization has weakened labor by depriving workers of their sense of solidarity, their confidence in their leverage and in their ability to bring employers, whole industries, and even whole economies, to their knees. Above all, the plausibility of capital's exit threat has-at least temporarily-undermined the capacity of workers to actualize whatever potential for class power they may objectively still have. Globalization has also undermined the political power of labor by appearing to reduce the impor- 
tance of state power as it seems to transfer sovereignty to internationalized capital. And so capital has been able to break another compact.

Does this story stand up any better than the one abou1 the poor laws? In their recent book, where their arguments are developed more fully, Piven and Cloward seem to sugges 1 that the latest "compact" started in the 1930s, continued, re-started, or intensified after the war, and was expanded to previously excluded groups in the 1960s. But whenever it started, it's clear that it ended with the political mobilization of neo-liberalism in the $1970 \mathrm{~s}$.

A surprising number of people on the left talk, like Piven and Cloward, about compacts of one kind or another between capital and labor. For instance, many speak of a post-war "accord" between the classes in the United States after the Second World War. In that accord, "Keynesian" state intervention and the welfare state combined with a settlement at the microeconomic level in which labor conceded control of the labor process to capital in exchange for wage increases in keeping with productivity gains and inflation. Some commentators seem to treat this post-war accord as if it ushered in some kind of "golden age," while others are inclined to call it a betrayal by the "labor bureaucracy." But either way, for people who think in terms of a post-war accord, the electoral triumph of neoliberalism, in the persons of Margaret Thatcher and Ronald Reagan, is as close as we can get to a precise moment when globalization ended that compact.

Let's, then, work back from this turning point. In what way, if any, does it mark a watershed between a social compact and its breach? What did it bring to an end?

The decline in the labor movement and the dismantling of the welfare state are obviously not illusions-though they mean more in countries that have actually had a welfare state worth talking about, which is not self-evidently true of the United States when compared to, say, the Scandinavian countries, or even Canada and Britain. In certain European cases, notably in Scandinavia, there may even be some justification for talking about the kind of "compact" Piven and Cloward 
lave in mind. And the post-war "settlement" in Britain was indoubtedly driven by capital's fear of militant (and hopeful) vorking-class soldiers returning from the war. There is no loubt that the neoliberal program, now adopted even by social democratic regimes, marks a significant departure from hat distinctive post-war moment. But let's put things into perspective.

Let's talk about the United States in particular. The first important point about the post-war "golden age" is its uniqueness. ${ }^{4}$ For the United States, the early post-war period was a historically unprecedented and almost certainly unrepeatable "conjuncture." What was truly remarkable was the unrivalled hegemony of the United States and its relative freedom from competition. But the economic breathing-space was short (its loss only partially offset by continued military superiority and spending), as two other major players, the two defeated powers, Germany and Japan, entered their own impressive periods of growth.

What about class relations? Was there, as is often argued, an "accord" in which labor and capital agreed to keep both wages and prices relatively high by means of mutual concessions? There may have been a short period of relative calm in the war against labor while the lack of competition allowed capital to tolerate higher wages - though we shouldn't forget that the 1940s were the years of the Red Scare, the Taft-Hartley Act, and the beginning of the Cold War. If wages continued to rise for a while (at least in some parts of the country) even when, in the context of increasing competition, they seriously threatened profits, it was primarily because of rank-and-file militancy. But capital didn't sustain the squeeze on profits for long. If there was ever a truce in its class war against labor, it didn't last. In the late 1950 s and the 1960 s, class conflict heated up. U.S. capital, now facing renewed and intensified competition, launched a vicious and sustained attack on labor.

So while labor certainly lost control of the labor process (and, as some versions of the "accord" model point out, elements in the labor bureaucracy certainly collaborated in U.S. imperialist policies), it's hard to see this as an "accord." 
We have to keep in mind that the so-called golden age was a period when capital sustained its profits not by "accords" so much as by vicious class conflict: from Taft-Hartley in the late 1940 s, to union-avoidance strategies by companies like IBM or deunionization strategies by General Electric in the late fifties and early sixties, to savage bouts of union-busting and "some of the worst storms in labor history" in the late fifties, followed by a decade of union unrest from the early sixties to the early seventies, with a rank-and-file chafing against their leadership's inadequate responses to attacks by capital. "It is generally forgotten," writes Mike Davis, "how close American industrial relations came to a raw re-opening of the class war in those years. "5ar from representing a time of concord, or even a cease-fire, between the two classes, the "golden age" was a time of unrelenting assault by capital against labor.

If there was an ebb and flow in capital's war against labor during the "golden age," it was not only a matter of changes in working class power or militancy. It had a great deal to do with the beginning and end of U.S. capital's unique moment of unchallenged ascendancy. The idea of the "compact" makes that moment seem too voluntary and therefore possibly recoverable, instead of historically specific and unrepeatable. On the one hand, this tends to lay the blame for deteriorating conditions mainly on the failures of organized labor. On the other hand, if some labor leaders today still believe they can go back to a "golden age," the notion of the "compact" or "accord" may be partly responsible for that illusion.

The compact model doesn't look much better if we move further back, as Piven and Cloward seem to do, in search of the compact, to the 1930 s and the New Deal. It's certainly true that labor organization in the United States reached a high point in the 1930 s, and without some heroic class struggles there would have been no New Deal. But the correlation between the policies of the New Deal and the disposition of class power is far from simple and direct, and it is very hard to think of it as just a compact in which capital conciliated labor. 
I see no reason to question the often repeated observaion that the New Deal saved capitalism, and was intended to ave capitalism. It was, of course, done against the will of most (though not all) capitalists and against their resistance at every itep. In that sense, the New Deal represents a disjuncture between the state and the capitalist class. But, as in the case of he old poor laws, it's hard to say that this disjuncture was imply determined by the strength of labor against capital, or hat it acted against the interests of capital in favor of labor. Nor was the weakness of capital in that moment of extremity n direct proportion to labor's strength. On the contrary, it was the consequence of a deep economic crisis that profoundly affected both classes-and we surely wouldn't want to say that the effects on labor were unambiguously empowering.

While any social and political gains for the working class, both before and after the war, were never freely given without class struggle, there was never a simple and straightforward correlation between social provision and the disposition of class power of the kind suggested by the compact model.

The Second World War marked-and basically causedthe transition from depression to boom. Economic conditions in the post-war boom were exactly the reverse of those in the 1930s. In one case depression (the weakness of capital?) and in the other case economic boom (the strength of capital?) constituted the conditions for social reform. Even if the prewar reforms can be explained by the organization and militancy of labor while capital was reeling from the Depression, what power relation explains the "golden age" after the war? It would be hard to prove that the power of labor surpassed the increasing strength of capital, and even harder to show that capital had been forced to call a truce in its war against labor. So the interplay of economic conditions and class power is clearly more complicated than the compact model or the theory of epochal shifts and "power eras" suggests.

What about the breach of the compact? There is no doubt that the signs of decline-in the proportion of unionized labor, in welfare, provision, and so on-have been especially dramatic since the early eighties. But, as Harry Magdoff re- 
minds us in this issue's "Review of the Month," "the spirit o. neoliberalism" was already present much earlier, at the heigh of the so-called "age of Keynesian social democracy." No: should we forget that in the United States the decline in unior: density began in the fifties, and continued as new industrie: developed, especially in the South and Southwest, without a corresponding organization of the new labor force (maybe as critics of the labor bureaucracy will tell us, because these regions were deliberately conceded to capital-but if this is the "accord," it means something rather different from wha1 Piven and Cloward seem to have in mind).

There are other problems too. If we identify the breach with the electoral triumph of neoliberalism, should we say that Thatcher's election was a response to the weakness of labor or, on the contrary, to the period of labor militancy that preceded her victory? Once again as in the case of the poor law reform, maybe the mobilization of capital had less to do with labor's weakness than with its strength. Such an explanation has flaws of its own, but it is no less, and probably more, plausible than the other. In any case, it does at least illustrate, yet again, the complexity of the relation between class power and the welfare state.

But suppose we set aside the compact theory and argue instead that, with or without a sudden and dramatic rupture, the long decline of the labor movement and the welfare state corresponds to the long-term process of "globalization," which reached a climax some time in the seventies.

Even here there are problems. We all know, of course, that the drive for expansion and internationalization belongs to the very nature of capitalism and has been evident since the beginning. The Communist Manifesto, composed a century and a half ago, contains as graphic a description of "globalization" as anything written today.

What, then, is new? One new feature on which everyone seems to agree is the breath-taking mobility of finance capital, perhaps the only feature that justifies the hype about the "information age" and the dramatic effects of the new technologies. But what is striking about the process of "globaliza- 
tion" in the past two or three decades, especially in the United States, is how little any of the major changes ascribed to it can be laid at the door of cyber-finance. Other aspects of "globalization," notably the internationalization of production and competition from third world economies with cheap, unregulated labor, have certainly played a significant role-though often (as Piven and Cloward point out) more as a threat than as a reality. But even this can't explain the end of the post-war "golden age."

If there was one major economic change that altered the course of economic development in the United States, ultimately leading to the end of the "golden age," it was not the technological revolutions in financial markets, nor a flight of capital to Mexico, but earlier competition from other advanced capitalist economies. If there has been an epochal change in the United States, it dates from the economic recovery of the main defeated powers after the Second World War. That also raises some interesting questions about whether globalization represents just the power of capital or also its vulnerability-but I'll come back to that in a minute.

The picture that emerges here is of a typically expansionary capitalism, "globalizing" over the long term-in fact, from the beginning-and just as typically marked by regular crisis and continuous class conflict. If this century has seen any cataclysmic episodes that mark an epochal shift in the capitalist economy, especially in the United States, they have been depression and war. These episodes have, of course, had substantial effects on the welfare state. In the United States, for instance, depression and war enabled and/or forced a temporary shift in the balance between social provision and market compulsions. That shift could not long survive an economic downturn, the roots of which can be traced to the resumption and intensification of competition among advanced capitalist economies. So maybe what we're talking about is not so much an epochal shift as a return to form, to the typical logic of capitalist development and change. 


\section{A Really New Power Era?}

So Piven and Cloward's model of epochal shifts is no more convincing in the case of the modern welfare state than it was in the case of the poor law reform. What is it, then, about this "epochal shift" that so many people find so compelling, and what difference does it make? Its attractions for capitalist ideologues are clear enough. There is no more convincing argument for TINA (There Is No Alternative) than the insistence that history has taken some irrevocable turn, closing off options-like social democracy, let alone socialism-which may at one time have looked attractive and possible but are now a thing of the past. The appeal of such arguments to socialists, though, is rather more mysterious.

Piven and Cloward may give us a hint. "We are all social democrats now," they say. That, in a sense, is the main theme of their challenge to "the emerging $M R$ position" on globalization. We are all, they say, nostalgic for the traditional certainties about the working class and the possibilities of class struggle in the "industrial era," the era of big unions, labor parties, and mass strikes-all those things that helped create the welfare state but which globalization has effectively destroyed. And we mourn the passing of all those old formations and all those old possibilities. That nostalgia is, they claim, what lies behind MR's refusal to acknowledge that something fundamental has changed with globalization and that we on the left have suffered a truly "awesome" loss.

But it occurs to me that something else is going on, which I can sum up with my own aphorism: "There are no social democrats now." People are waking up to the fact that social democracy is not a viable option. For those who have tended to identify social democracy with socialism, there seems to be no other alternative to capitalism-in fact, no alternative to the more inhumane, neoliberal forms of capitalism. So the loss of social democracy is for them indeed an awesome one. It is for them a more cataclysmic and perhaps even final loss than for those who, while certainly supporting the welfare state or any amelioration of capitalism's destructive conse- 
quences, have always doubted the long-term sustainability of capitalism "with a human face." Those who used to place all their hopes in social democracy are inclined to explain their awesome loss not by conceding that a humane capitalism was never sustainable in the long term but by invoking some massive epochal shift which has destroyed the foundations of what used to be, but no longer is, a real possibility. ${ }^{6}$

Piven and Cloward seem to have mixed feelings about this. What they say about social democracy reads like an epitaph. Yet they hold out the hope of a resurrection-or at least a reincarnation in another form, some new kind of compact, some new way of making capitalism tolerable. There is, though, no hint of anything more. The "compact" model implies that what the left should be aiming for, and all we can hope for, is to wring concessions from capitalists-as earlier generations wrested concessions from the capitalist class on poor relief, which they later lost, and as workers in the "industrial" era have won and lost the welfare state. This idea that the object of working-class power is to wring concessions from capital within a capitalist system nicely sums up the essence of social democracy-especially together with a theory of history in which changes of government may look like major epochal shifts, if only because fundamental transformations of property and class relations have, in effect, been ruled out.

I agree, of course, that class power is what it's ultimately all about. And I don't want to take issue with the very useful and illuminating things Piven and Cloward say about the formation of working-class power, about the processes of organization and ideological penetration. ${ }^{7}$ The problem I have with their argument concerns their account of what working-class power is for, or what it can and can't accomplish in the context of capitalism.

My point is simply this: there is no such thing as a compact between capital and labor in any meaningful sense. The system is constituted by the fundamental class antagonism at its heart, and within the confines of the system, the capitalist class always, by definition, has the advantage. That may help to explain, among other things, how capital can 
mobilize in response not to the weakness of labor but to its strength and yet still win the day. Class struggle is a constant necessity to ward off the worst excesses of exploitation, and the working class has had a long and heroic history of achievements in that respect. Class struggle has, paradoxically, also been necessary to save capitalism from itself and its inherently destructive, even self-destructive, drives. But within the confines of the system, the victories of working-class power, even at its highest points, will always be severely constrained and fragile. A strategy limited to the objective of wringing concessions from capital, while it may be all that is possible in certain conditions, is in the long run self-defeating.

Yet I believe that working-class power can do a great deal more than wring concessions from capital. Socialism still remains a realistic option-more realistic than capitalism with a human face. But even short of socialism, and as part of the struggle to attain it, there is a difference between just struggling to win concessions from capital and struggling to wrest control away from capital, a difference between striving for "safety nets" within the capitalist system and striving instead to detach the conditions of life from the logic of capitalism. There is, in other words, a difference between seeking some elusive and short-term class compact and challenging the underlying class relation itself.

The question, then, is whether today's conditions are more or less conducive to those more ambitious goals and to the more combative methods needed to achieve them, and whether what people are calling "globalization" detracts from or enhances the possibilities of struggle.

It may be that the conditions have never yet been right for a truly socialist struggle-not just for the achievement of socialism but even for less final challenges to capitalism, struggles not just to win concessions from capital within a capitalist system but to oppose the system itself with an economic logic of a different kind. In an underdeveloped capitalism, the material conditions are simply not there. But in cases where the productive forces have been sufficiently developed to make socialist alternatives possible, the very same 
conditions that have made them so have had a contradictory effect on working-class unity, organization, and ideology.

There hasn't been the kind of unambiguous relationship between the development of industrial capitalism and the growth of a united and powerful working class which Marxists once expected. Industrial capitalism-and here I depart from much of conventional Marxist wisdom (and from the assumptions that Piven and Cloward attribute to Marxists) - has also militated against working-class unity, fragmenting the working class and turning it inward, away from the centers of capitalist power toward the individual workplace. Struggles at the point of production have, of course, been absolutely vital and still are, but they have also had a centrifugal effect on workingclass power and struggle. They have also marked a separation between "economic" or "industrial" struggles and political ones.

What we are seeing today may be the beginning of an era-a real epochal shift, maybe the first of its kind in the history of capitalism-in which the material and technological conditions for a truly socialist and democratic organization of material life are present, while for the first time new conditions are emerging that can overcome the centrifugal effects of industrial capitalism and reconnect economic with political struggles. Meantime, capitalism, having become a virtually universal system, no longer has the same scope for external expansion which used to save it from its internal contradictions, so it has become subject to those contradictions in historically unprecedented ways. This is what I've called the "universalization" of capitalism, which is indeed an important historical change.

Among the current contradictions is that capitalism no longer seems able to sustain maximum profitability by means of commensurate economic growth and seems now to be relying more and more on simply redistributing wealth in favor of the rich, and on increasing inequalities, within and between national economies, with the help of the neoliberal state. In advanced capitalist countries, the most visible sign of that redistribution is the decline of the welfare state. And while 
changes in the patterns of labor toward growing insecurity may have more to do with this process of redistribution than with an absolute decline in the need for labor, the ability of capitalism to absorb a growing reserve army of labor is at least open to question. The result may be to break the old pattern, to upset the long-standing balance, that has up to now repeatedly saved capitalism from itself-the balance in which the danger of social unrest and disorder has been met not only by direct coercion but also by social provision.

Piven and Cloward conclude their piece by hinting at new possibilities. What I'm saying is that those possiblities may be closer than we think-and precisely because of "globalization." "Globalization" is not just about the power of capital. It is also about the vulnerability of capital subjected to the pressures of international competition and its own internal contradictions. Besides, I don't accept the premise of the "globalization thesis"-which Piven and Cloward never quite contradict-that the importance of the state and political power declines in proportion to globalization.

On the contrary, I think (as I have been repeating far too often, and as Harry Magdoff explains in this issues' Review of the Month more clearly than I have ever been able to do) that capital now needs the state more than ever to sustain maximum profitability in a global market-so much so, I would say, that working-class political power could now challenge capital in ways it never could before. And with the "globalizing" state as a target of struggle-we've been seeing unprecedented examples of this kind of struggle in many parts of the world in the last few years - there now exists a focus for working-class solidarity, within and across nation-states, of a kind that has never before existed in advanced capitalist countries.

So it may indeed be the beginning of a new-a really new-power era. 


\section{VOTES}

1. Frances Fox Piven and Richard Cloward, The Breaking of the American Social Compact (New Press, 1997), pp. 13-14.

2. In case it needs emphasizing, I'm not here rejecting, nor have I ever rejected, the idea of epochal shifts as such, though I think it would be difficult to find any epochal shifts that meet Piven and Cloward's criteria. And I certainly have never denied that capitalism changes. On the contrary, I emphasize that capitalism constantly changes. The point is that we have to understand the processes of change. Sometimes the concept of "epochal shifts" is a way of avoiding the issue, as we leap from one "epoch" to another while losing sight of historical process.

3. E. J. Hobsbawm, Industry and Empire (Penguin, 1975), p. 229.

4. The following discussion of the post-war period is indebted to Robert Brenner's forthcoming book, Uneven Development and the Long Downtum: the Advanced Capitalist Economies from Boom to Stagnation (Verso, 1998), Part Two, especially section II.

5. Mike Davis, Prisoners of the American Dream (Verso, 1986), p. 123.

6. I owe to John Mage this explanation of why so many on the left feel compelled to talk about "globalization" as a massive historical transformation of epochal proportions, different from the changes that capitalism regularly undergoes.

7. I'm not sure, by the way, why they think that 1 , or anyone else at $M R$, believes that there is anything automatic about the "actualization" of working-class power. See, for example, my argument in The Retreat from Class (Verso, 1986), chapters six and seven. I have also consistently argued, contrary to some conventional Marxist wisdom (and contrary to the assumptions Piven and Cloward attribute to Marxism), that the development of industrial capitalism does not automatically and unambiguously promote the growth of working-class power but that, on the contrary, the very structure of a mature industrial capitalism has a centrifugal effect on class struggle, a fragmentation of the working class, together with a tendency to drive a wedge between "economic" or "industrial" struggles and political ones, which requires difficult ideological and organizational processes to overcome. See, for instance, Democracy Against Capitalism: Renewing Historical Materialism (Cambridge, 1995), chapter One, based on an article originally published in New Left Review in 1981; and my introduction to this year's summer issue of $M R$.

8. For a discussion of socialist-as distinct from social democratic-alternatives in societies that are still capitalist, see Greg Albo, "The World Economy, Market Imperatives, and Alternatives," Monthly Review (December, 1996); and Sam Gindin, "Notes on Labor at the End of the Century: Starting Over?" Monthly Review (July/August, 1997).

I'd like to thank Bill Fletcher Jr. for his very helpful comments, though he won't necessarily agree with everything I say. 


\title{
A REPLY TO ELLEN MEIKSINS WOOD
}

\author{
by FRANCES FOX PIVEN and RICHARD A. CLOWARD
}

\author{
Ellen Meiksins Wood puts the difference in our positions \\ succinctly: ${ }^{1}$
}

Piven and Cloward attribute both too much and too little to class struggle. They expect too much of it in the sense that they count on it to make life tolerable within the confines of capitalism and the strictures of the capitalist market. But in another sense, they ask to little of class struggle: the best it can do is-occasionally and temporarily-to make life more bearable within the capitalist system. If ... they're too optimistic about the sustainability of capitalism "with a human ... face," they're too pessimistic about the possibility of transcending capitalism altogether.

The one qualification we would add is that we are neither pessimistic about "the possibility of transcending capitalism altogether," nor optimistic. ${ }^{2}$ We take no position on socialism; indeed, we are unclear about what it now means, as are most people on the left. Moreover, we see little reason for either agreeing or disagreeing with Wood's speculation that a "universalizing" capitalism will make it more vulnerable to its internal contradictions and thus more vulnerable to transformation. The speculation about a coming transformative moment has to us an apocalyptic quality.

In the meanwhile, people struggle to survive with a measure of dignity under capitalism. Their victories, including programs to replace income when workers become unemployed, disabled, or too frail to work, certainly fall short of transformation, or we suppose of socialism. Neverthe- 
less, people are better off with such life supports than withwut them (and that includes outdoor relief in earlier times). Ve do not exalt welfare state programs. We understand their : mbiguities, limitations, and inadequacies as well as anyone Ise, as our numerous critiques of welfare state programs ittest.

To our minds, then, the key questions are what people an win under "actual existing capitalism," and how can they vin it? What are the potential sources of power under specific iorms of capitalism? This is not to deny that there are also continuities in capitalism, as Wood argues, that its manifestaions at any particular time were in some measure present in earlier times, just as there was always class struggle. But it is also true that the changes in capitalist economic and political relations from one time to another are extremely significant because they help to determine the specific forms of power from below that are possible. In a time of commercial agriculture, displaced peasants could burn the fields of the landlords and perhaps win outdoor relief; in a time of industrialization, workers could sabotage the machines or strike, and win social welfare programs.

Just as important, historical change alters the conditions that make it possible for people to actualize the power yielded them by capitalist relations. As capitalism reorganizes, old forms of popular solidarity may be shattered, and old understandings of the possibilities of power from below may become discredited. With time, of course, new solidarities are constructed, along with new understandings that reflect the new relations created by a capitalist political economy. As a result, class power relations shift, and these shifts we think demarcate important eras within capitalism. To be sure, any attempt to impose a periodization on a densely complex history is subject to argument. Nevertheless, we think it indisputable that class power relations have changed over the course of a centuries-long capitalist history, in a pattern that is neither evolutionary nor continuous.

These shifts reflect not continuities but changes in capitalism, and the effort of people to build power out of those 
changes. That is what interests us: Given their concrete historically specific circumstances, what can people wrest from their rulers, and how can they do it?

\section{NOTES}

1. Readers may be confused because she typifies our position by quoting not from our article in this issue, but from the introduction to our recent book The Breaking of the American Social Compact.

2. While we agree with this summing up of our position, Wood does misstate our argument at some key points along the way. We most decidedly do not think that "Globalization has ... undermined the political power of labor by appearing to reduce the importance of state power as it seems to transfer sovereignty to international capital." Indeed, in our recent book to which she refers we characterize this and related arguments as "The Globalization Hoax."

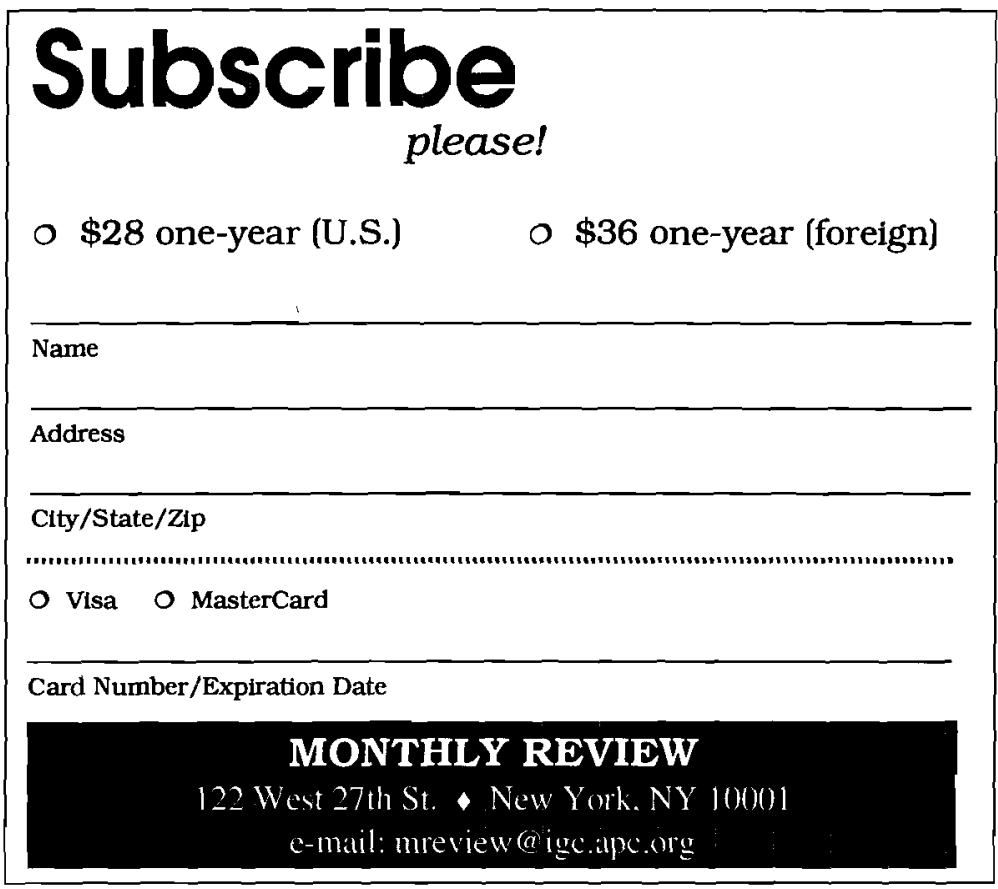




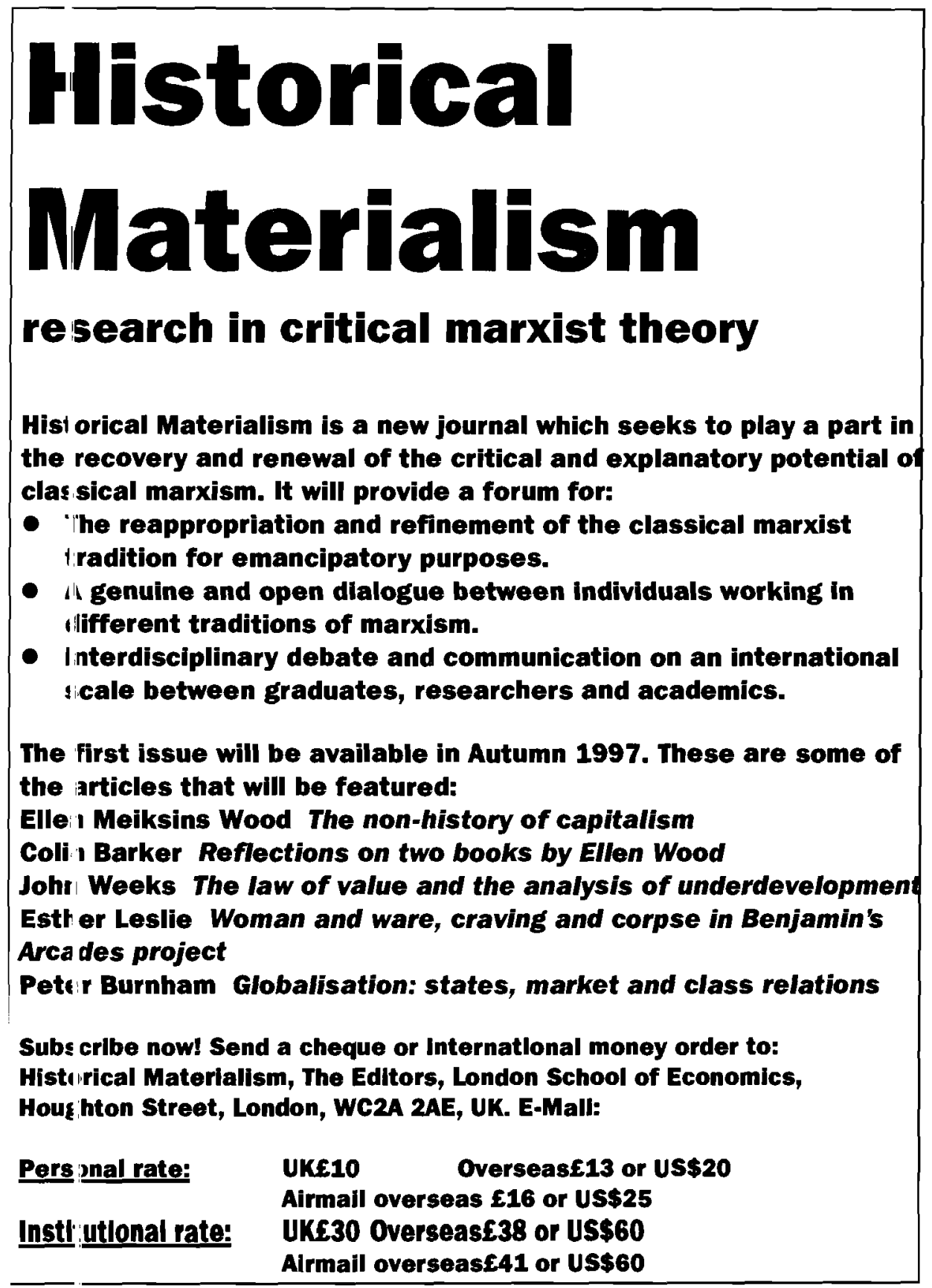

